ljtihad: Jurnal Wacana Hukum Islam dan Kemanusiaan

Vol. 18, No. 2 (2018), pp. 193-210, doi : 10.18326/ijtihad.v18i2.193-210

\title{
Membongkar praktik kawin friend para wanita sosialita di Surabaya
}

\author{
Nasiri \\ STAI Taruna Surabaya \\ E-mail: nasiri.abadi@yahoo.co.id \\ DOI : 10.18326/ijtihad.v18i2.193-210
}

This research departed from three questions. The first, how does the practice of marriage friend for careers women in Surabaya? The second, why the practice of marriage friend for careers women in Surabaya? The third, how about Islamic law seen marriage friend practices for careers women in Surabaya? In order to answer the questions above, researcher conducted a qualitativer research using cass aproach. The necessary data of this study was collected by interview, observation, and revier of documentation. In order to articulate construction of careers women in Surabaya, which has collected data were analyzed using an inductive method. The results of this study indicate that there are two models of friend marriage in Surabaya. First, they practice friend marriage by looking for potential husbands through friends or the mass media and looking for religious leaders who can marry them. In this marriage the woman frees her husband from all obligations. Second, they chose the practice of marrying friends by finding their own husband and after finding them married at a distant or foreign place and usually this marriage ended after having a child.There are two reasons that Surabaya socialite women choose the practice of marrying a friend. First, the reason for the manivest is where they conduct this friend's marriage to free husbands from all obligations. Second, the latent reason, where they do this friend's marriage solely to seek biological satisfaction.Jurisprudence scholars disagree in addressing the practice of friendship in Surabaya. Some allow it because they see the terms of the marriage pillar have been fulfilled. There are those who forbid this friend's marriage model, this is because of the motivation caused by this friend's practice. According to them, this friend's marriage model is no different from gigolo rental practices.

Penelitian ini bertolak dari tiga pertanyaan. Pertama, bagaimanakah praktik kawin frienddi Surabaya? Kedua, mengapa terjadi praktik kawin friend bagi para wanita karier di Surabaya? Ketiga, bagaimanakah pandangan hukum Islam mengenai praktik kawin friendbagi para wanita karier di Surabaya? Dalam rangka menjawab pertanyaan-pertanyaan di atas, peneliti melakukan penelitian kualitatif dengan menggunakan pendekatan kasus. Data yang diperlukan dalam kajian ini dikumpulkan dengan metode wawancara, pengamatan dan telaah dokumentasi. Dalam rangka mengartikulasikan prilaku para pelaku 
ljtihad: Jurnal Wacana Hukum Islam dan Kemanusiaan, Volume 18, No. 2, Desember 2018: 193-210

kawin friend tersebut, data yang telah terkumpul dianalisis dengan menggunakan metode induktif. Hasil penelitian ini menunjukkan bahwa ada dua model perkawinan friend di Surabaya. Pertama, mereka melakukan praktik kawin friend dengan cara mencari calon suaminya melalui teman atau media massa dan mencari tokoh agama yang dapat mengawinkan mereka. Dalam perkawinan ini pihak wanita membebaskan suami dari segala kewajiban. Kedua, mereka memilih praktik kawin friend dengan cara mencari sendiri calon suami dan setelah menemukan mereka melangsungkan pernikahannya di tempat yang jauh atau luar negeri dan biasanya perkawinan ini berakhir setelah mempunyai anak. Ada dua alasan para wanita sosialita Surabaya memilih praktik kawin friend. Pertama, alasan manivest (nyata), dimana mereka melakukan perkawinan friend ini untuk membebaskan para suami dari segala kewajiban. Kedua, alasan laten (tersembunyi), dimana mereka melakukan perkawinan friend ini sematamata untuk mencari kepuasan biologis. Ulama fikih berbeda pendapat dalam menyikapi praktik kawin friend di Surabaya. Ada yang memperbolehkan karena mereka melihat syarat rukun pernikahan sudah dipenuhi. Ada yang yang mengharamkan model kawin friend ini, hal itu dikarenakan madarrat yang diakibatkan dari praktik friend ini. Menurut mereka model kawin friend ini tidak ada bedanya dengan praktik sewa gigolo.

\section{Keywords: Marriage; friend; career woman}

\section{Sejarah munculnya kawin friend}

Masyarakat di negara-negara Timur Tengah mengikuti sistem patrilineal. Di sana, masyarakatnya sangat menjunjung tinggi sistem patriarki. Semua urusan publik, dikendalikan oleh para lelaki. Bahkan dalam urusan rumah tangga pun, kaum laki-laki sangat mendominasi. Hal itu bisa dilihat apa yang terjadi di pasar-pasar yang ada di Arab Saudi, Yaman, Mesir dan lain sebagainya. Mulai dari yang menjual hingga pembeli, rata-rata laki-laki. Para wanitanya sangat tertutup dan tidak boleh keluar rumah. Mereka hanya berdiam diri dalam rumah sambil siap-siap melayani jika suatu waktu suaminya memerlukan dia (Fahmi, 2007: 45).

Memang demikian, masyarakat Timur Tengah dikenal sebagai masyarakat yang sangat tertutup, khususnya dalam hal seksualitas. Mahar perkawinan yang terlalu mahal telak menjadikan banyak laki-laki tidak mampu untuk membayarnya (Hakim, 2000: 89). Dengan demikian, orang yang tidak punya kemampuan untuk membayar mahar akan sulit mendapatkan jodoh di dalam kehidupannya. Akibatnya, banyak laki-laki melakukan prilaku seks menyimpang, sementara bagi kaum perempuan banyak yang merelakan dirinya untuk dimadu karena persoalan mahar ini (Haqiqi, 1997: 17). Di Negara Arab Saudi, banyak perempuan yang merelakan diri jadi istri kedua, ketiga, atau keempat (Subhan, 2010:5). Hal ini terjadi karena tradisi patriarki memang berkembang kuat di sana, di samping juga karena 
Islam memperbolehkan laki-laki berpoligami.

Di Arab Saudi, perkawinan bisa menelan biaya ratusan ribu riyal. Umumnya seorang mempelai wanita meminta mahar 50.000 riyal hingga 250.000 riyal, setara dengan Rp 125 juta hingga Rp 600 juta. Selain mahar, calon suami harus sudah menyediakan rumah/apartemen dan kendaraan, plus simpanan deposito bagi calon istri (Hifni, 2008: 34). Ini semua dilakukan agar ketika terjadi perceraian, sang istri punya "sangu" untuk bertahan sampai ia dilamar untuk mekawin lagi. Jumlahnya sesuai permintaan sang calon istri (Syamsuri, 2010: 12). Total, biaya untuk satu perhelatan haflah zafaf (pesta perkawinan), calon suami sedikitnya menyiapkan dana 400.000 riyal- 500.000 riyal. Khusus bagi warga Saudi yang kurang mampu secara ekonomi, ada salah satu lembaga sosial yang khusus menghimpun dana untuk membantu warga yang berniat mekawin, tapi tak mampu secara keuangan (Nur Syam, 2010: 12).

Dr. Abd Raziq, salah seorang mab'üth Jämi' al-Azhar, mengatakan bahwa masyarakat Timur Tengah, khususnya masyarakat Mesir, dalam perkawinan, para wanita memperoleh posisi tawar yang sangat kuat. Pria tidak memiliki hak atas rumah dan isinya. Sejak menjelang perkawinan, orang tua wanita lazim meminta mahar dalam jumlah yang sangat besar, yakni rumah atau apartemen dengan segala pera-botnya. Jika tidak bisa, perkawinan dapat dibatalkan. Meskipun, secara hukum dan agama perkawinan tersebut sudah sah (Abd. Raziq, 2010: 15).

Karena itu, banyak pria yang mengeluhkan tradisi tersebut. Mereka merasa berat jika harus membeli rumah dan segala perabotnya yang bernilai puluhan atau ratusan ribu pound sebagai syarat perkawinan. Tidak heran, di Mesir banyak pria melajang dan baru berkawin ketika usia mereka sudah cukup tua. Yaitu, saat mereka sudah mapan secara ekonomi dan bisa membeli rumah dengan segala isinya. Mereka lantas mekawin dengan wanita-wanita yang jauh lebih muda. Adalah lazim menemukan pasangan suami istri yang usianya berbeda jauh seperti itu. Sang suami sudah tua, istrinya masih sangat muda, dan anak-anaknya masih balita(Abd. Raziq, 2010: 15).

Maka, tidak sedikit pria Mesir yang ingin kawin dengan wanita non-Mesir, termasuk mahasiswi Indonesia. Penyebabnya bukan hanya murahnya maskawin dengan wanita nonMesir, melainkan juga posisi tawar pria dalam rumah tangga yang sangat lemah ketika mengawini wanita Mesir. Betapa tidak, sebelum mekawin mereka harus bisa mengumpulkan 
ljtihad: Jurnal Wacana Hukum Islam dan Kemanusiaan, Volume 18, No. 2, Desember 2018: 193-210

biaya ribuan pound untuk membeli rumah dan segala isinya. Ketika mekawin, semua dihadiahkan kepada keluarga istri, diatasnamakan keluarga ataupun istrinya (Helmy, 2005: 12). Bila terjadi perceraian, sang suami bakal jatuh miskin karena diusir sang istri dari rumah yang dibelinya. Bisa-bisa dia keluar dari rumah dengan hanya berbekal pakaian seadanya.

\section{Pengertian kawin friend}

Tidak ada definisi yang pas untuk kawin friendini, akan tetapi setalah ia melihat prakek kawin friend yang terjadi di masyarakat, maka ia memberikan satu gambaran mengenai kriteria "kawin friend" yaitu perkawinan seorang laki-laki dengan seorang perempuan yang tidak tinggal satu rumah. Selain itu, laki-laki tersebut tidak dikenai kewajiban untuk membayar nafkah dan biasanya pihak laki-laki sudah punya istri, sehingga perkawinannya harus dirahasiakan dari pihak istri yang pertama (al-Qardawi, 2001: 289).

Ada pengertian lain terkait kawin friend, yaitu kawin yang dilakukan oleh perempuan kaya dengan seorang laki-laki pilihannya, dengan cara laki-laki tersebut mendatangi rumah perempuan, keduanya tidak tinggal dalam satu rumah tangga, pihak laki-laki dibebaskan dari segala tanggung jawab yang biasa ditanggung oleh para suami seperti nafkah, tempat tinggal, qasm dan mabit, dan perkawinan ini hanya untuk waktu yang ditentukan, serta dirahasiakan dan tidak boleh diketahui oleh orang lain, terutama pihak istri (Mulk, 2006; 54).

\section{Perbedaan kawin friend dengan kawin 'urf}

Antara kawin friend dan kawin ' $u r f i$ ada perbedaan dan persamaan. Keduanya mempunyai hubungan al-'umüm wa al-khusūs bi wajbin (umum dan khusus dalam satu segi). Kawin 'urfi adalah kawin yang dilakukan sesuai dengan cara shara', hanya saja perkawinan ini tidak tertulis dan terdata, sehingga tidak ada bukti bahwa keduanya sudah melangsungkan perkawinan (Al-Qardawi, 2002: 399). Kawin 'urfi sama layaknya dengan kawin biasa, yaitu seorang suami bertanggung jawab kepada istrinya memberikan tempat tinggal dan juga nafkah. Pada umumnya, si suami telah terlebih dahulu mempunya istri sehingga perkawinan ini dirahasiakan agar istrinya tidak mengetahuinya(Kodir, 2010: 20).

Praktik kawin friend, di samping tidak dicatat juga bagi seorang suami tidak ada istilah tanggung jawab. Suami tidak dituntut kewajiban menyediakan tempat tinggal maupun nafkah, sebab kawin friend yang sangat membutuhkan pasangan adalah istri (Jones: 2001;24). 
Oleh karena yang sangat membutuhkan pasangan adalah dari pihak istri, maka tentu segala kebutuhan dan lainnya ditanggungnya sendiri, sedangkan si suami hanya berkewajiban mendatangi dia seminggu, sebulan atau bahkan satu tahun sekali.Akan tetapi, meskipun dalam kawin friend tidak ada pendataan (tidak dicatat) dan juga tidak ada tanggung jawab dari pihak suami, Yūsuf al-Qarḍ̄awi tidak berani membatalkan model akad perkawinan ini dengan beberapa alasan:Pertama, pembatalan akad tersebut akan membawa dampak negatif, karena dapat berimbas adanya hukum baru dalam masalah hubungan suami istri (yaitu dapat menjadikan perbuatan zina yang diharamkan), dan lebih parahnya lagi, jika dari hubungan haram itu melahirkan anak, maka anak tersebut adalah anak haram.Kedua, kaum muslimin tempo dulu melakukan perkawinan dengan tidak disertai pendataan.Ketiga, dalam hukum ahwäal al-shakhsiyah (berhubungan dengan prilaku manusia) yang berlaku di negara-negara Arab, yang notabene mengharuskan pendataan ketika dilaksanakannya akad perkawinan, meskipun begitu dalam kawin 'urfi (dilakukan tanpa pendataan) dalam undang-undang mereka hanya ditetapkan "tidak diterima gugatan ataupun permohonannya, tetapi kawinnya tetap sah dan tidak batal" (Al-Qardawi, 2002: 240).

\section{Perbedaan kawin friend dengan kawin mut'ah}

Sebagian orang yang menentang dilaksanakannya kawin friend.Salah satu alasannya adalah karena menganggap kawin friend sama dengan kawin mut'ah. Yūsuf al-Qarḍ̄āwi menegaskan bahwa perbedaan antara kawin frienddengan kawin mut'ah sangat jelas, di antara perbedaan tersebut sebagai berikut:Kawin mut'ah adalah kawin yang dibatasi oleh waktu dan ditentukan dengan imbalan yang jelas. Biasanya mahar atau imbalan yang diberikan oleh laki-laki kepada perempuan disesuaikan dengan lama tidaknya kontrak yang disepakati kedua belah pihak (suami istri). Kalau waktu yang ditentukan sudah habis dengan sendirinya kawin ini berakhir sekalipun tanpa talak, fasakh atau lainnya. Dalam kawin mut'ah, waktu adalah bagian yang tidak terpisahkan dari akad (Manan: 2008; 340).

Adapun kawin friend adalah kawin yang dilakukan dengan waktu yang tidak terbatas, dan bahkan sudah ada niatan untuk melanggengkan perkawinan tersebut.Dalam akad perkawinan ini tidak dibatasi oleh waktu tertentu.Sehingga kawin ini tidak berakhir kecuali dengan talak atau fasakh (Mulia, 2005: 54).Golongan Shi'ah memperbolehkan dilaksanakannya kawin 
ljtihad: Jurnal Wacana Hukum Islam dan Kemanusiaan, Volume 18, No. 2, Desember 2018: 193-210

mut'ah, tetapi tidak menganggap istri yang dikawini secara mut'ab ini termasuk empat istri yang diperbolehkan untuk dikawini.Dengan kata lain, seorang suami boleh mekawini secara mut'ah beberapa perempuan secara bersamaan, sekalipun melebihi dari empat orang (Ali Ahmad, 1997: 180).

\section{Praktik kawin Friend di Surabaya}

Dalam penelitian ini, yang dimaksud dengan Surabaya itu adalah kota Surabaya dan sekitarnya, yang mencakup Kota Surabaya, Kota Pasuruan, Kota Malang, Kota Gresik, Kota Sidoarjo, dan Kabupaten Bangkalan. Namun yang fokus utama dalam penelitian ini adalah kota Surabaya.

Surabaya, sebagai ibu kotaSurabaya, termasuk kota terbesar kedua setelah Jakarta. Meskipun demikian, kota Surabaya tetap menjadi kota yang indah dengan panorama kota yang tertata dengan cukup rapi. Menanggapi kenyataan ini pula secara logis kebutuhan akan hunian yang nyaman juga sangat dibutuhkan untuk pertumbuhan kota Surabaya ke depan. Memang pada mulanya masyarakat Surabaya banyak yang tinggal di daerah perkampungan. Namun seiring berjalannya waktu, kini sudah banyak sekali bentuk-bentuk hunian yang bertaraf internasional dengan padang golfnya yang luas dan indah.

Misalnya, Perumahan Graha Family yang terletah di daerah Wiyung,Perumahan Palm Spring Regency yang terletak daerah Jambangan, Perumahan Bulak Rukem Timur yang terletak di daerah Pantai Kenjeran dan masih banyak perumahan-perumahan elit lainnya. Para penghuni perumahan-perumahan elit ini, hidupnya cenderung eksklusif, individualistik, dan tidak jarang di antara mereka yang belum begitu kenal dengan para tetangga kanan kirinya.Hal itu wajar sekali, sebab kebanyakan mereka adalah para pengusaha, pebisnis, wirausahawan, dan pejabat yang biasa berangkat pagi dan pulang malam, sehingga tidak ada waktu untuk mengobrol dan bertegur sapa dengan tetangga kanan-kirinya.

Peneliti mengamati para penghuni perumahan elit tersebut di atas, ternyata menemukan beberapa wanita yang hidup sendirian di rumah besar dan ada yang hanya ditemani dengan seorang pembantu.Ada yang masih 'gadis' tapi kebanyakan mereka janda. Mereka secara materi sudah cukup mapan dan sudah sangat siap seandainya mau kawin tapimereka kelihatannya tidak ada keinginan kawin. Para wanita tersebut, kelihatan orang beragama (Islam) dan taat beribadah, terbukti ketika ada pengajian rutinan di kompleks tersebut, mereka hadir dan 
tidak sedikit yang aktif dan berdiskusi tentang ke-Islam-an. Dari sinilah, kemudian peneliti bertanya-tanya “kenapa mereka tidak mau kawin padahal mereka orang beragama?” Peneliti mencoba mencari informasi lebih dalam lagi, dan akhirnya peneliti pun mendapat informasi bahwa "para wanita tersebut sudah bersuami dan suaminya tidak tinggal satu rumahnya". Informasi awal inilah yang dijadikan peneliti sebagai bahan untuk menghubung-hubungkan dengan trend model perkawinan abad modern. Hasilnya, peneliti menyimpulkan bahwa perkawinan yang mereka lakukan adalah perkawinan model kawin friend.

Model kawin friend adalah model perkawinan yang ditentukan oleh pihak perempuan. Pihak laki-laki hanya sebagai 'boneka' yang boleh dibawa ke mana pun dia mau.Adapun modusnya bermacam-macam.Ada yang melalui media informasi, teman, dan ada juga yang langsung mencari sendiri. Seperti yang dilakukan oleh Susi, pelaku friend, ia menuturkan bahwa perempuan yang hendak melakukan kawin friend biasanya mencari informasi dari teman atau media massa mengenai laki-laki yang hendak dipilihnya (Susi; 2017; 5). Setelah menemukan laki-laki yang cocok-biasanya laki-laki ganteng dan biasanya masih mudaia mengontaknya dan mencari mudi>n (tokoh agama) yang hendak mekawinkan mereka berdua. Artinya, yang terlibat dalam prosesi perkawinan friendini hanya beberapa orang saja. Calon mempelai berdua, dua orang saksi dan seorang mudin yang mau mekawinkan. Proses perkawinan friendseperti yang dilakukan oleh Lela inilah yang banyak terjadi di kalangan para wanita karier(Susi, 2017:5).

Berbeda dengan Susi, Bela justru melakukan kawin friend dengan caranya sendiri. Sesuai dengan pengakuannya, sebelum melakukan perkawinan friend, ia mencari laki-laki Asing yang datang ke-Indonesia dan akhirnya dia menemukan laki-laki Arab tinggi besar dan usianya agak tua. Akhirnya, mereka pun melangsungkan perkawinannya hingga membuahkan dua orang anak perempuan dan setelah itu mereka berdua berpisah (Bela, 2017: 4).

Demikianlah sekilas perbedaan kawin friend yang ada di Indonesia dengan kawin frienddi Timur'Tengah. Perbedaan itu khususnya terkait tujuan melakukan perkawinan, proses seleksi calon suami, proses perkawinan, masa perkawinan, dan juga wali yang mengawinkannya. Jika di Timur Tengah yang mekawinkan adalah walinya, maka di Indonesia yang mekawinkan adalah seorang mudin. 
ljtihad: Jurnal Wacana Hukum Islam dan Kemanusiaan, Volume 18, No. 2, Desember 2018: 193-210

Untuk lebih jelasnya, berikut ini penulis uraiakan secara terperinci mengenai perbedaan kawin friend di Surabaya dengan model kawin friend yang ada di Timur Tengah yang pernah difatwahalalkan oleh Muhammad Yūsuf al-Qarḍ̄āwì. Perbedaan itu terjadi dalam banyak hal, antara lain:Pertama, kawin friend di Surabaya, betul-betul dirahasiakan dari halayak umum, sedangkan dalam praktik kawinfriend di Timur Tengah, tidak dirahasiakan melainkan hanya tidak didaftarkan di kantor pemerintahan yang berwenang.Kedua, Suaminya dalam praktik kawin frienddi Surabaya, rata-rata masih muda, kekar dan kulitnya bersih dan putih, sedangkan kawin friend di Timur Tengah, tidak harus muda, yang terpenting dia mau kawin dengan wanita kaya tersebut.Ketiga, hubungan suami-istri kawin frienddi Surabaya, biasanya di lakukan di luar rumah—baik di hotel, apartemen, villa, rumah kontrakan, bahkan sampai di kamar kos-kosan — sedangkan di Timur Tengah, hubungan suami-istri biasanya dilakukan di rumah istri.Keempat, kawin frienddi Surabaya, tanpa diketahui oleh masing-masing pihak keluarga suami-istri, sedangkan di Timur Tengah, perkawinan tersebut sudah diketahui oleh masing-masing pihak keluarga suami-istri.Kelima, di Surabaya, yang mengawinkan mereka adalah mudin, sedangkan di Timur Tengah, yang mekawinkan mereka adalah para walinya. Keenam, kalau di Timur Tengah, semua wanita yang memilih model kawin friend tidak mempunyai suami, sedangkan di Indonesia—khususnya di Surabaya—ada sebagian yang berstatus istri orang lain.

\section{Alasan wanita sosialita Surabaya memilih kawin friend}

Alasan yang melatarbelakangi pemilihan model kawin friend ini bermacam-macam. Ada yang bermotif ingin terbebas dari hegemoni suami, ada yang motifnya tidak mau repot dengan urusan suami, ada yang berasalan karena kawin friend mirip dengan kawin sirri, ada yang bermotif agar tidak terlalu ribet ketika mau ganti pasangan, ada yang memilih kawin friendini hanya ingin coba-coba, bahkan ada juga yang melakukannya ingin memperbaiki keturunan. Untuk lebih jelasnya, berikut ini peneliti uraikan alasan-alasan para pelaku friend yang didapat dari data lapangan yang telah dihimpun oleh peneliti.

Pertama, terbebas dari Hegemoni Suami.Marmi, seorang wanita single parent yang kaya raya.Wanita karier yang tidak mau menyebut asal-usulnya ini bertemu dengan peneliti ketika peneliti berada di ruang tunggu bandara Juanda.Wanita yang merahasiakan identitasnya ini 
mengaku tinggal di komplek Perumahan Graha Family dekat Kecamatan Wiyung Surabaya. Sesuai pengakuannya, dia pernah melakukan praktik kawin friend.Sebagai wanita karier yang kaya raya dan cantik, tidak sulit baginya untuk mencari laki-laki yang bersedia menjadi suami kawin friend.Menurutnya, prosesi kawin friend itu simple dan tidak ribet sebagaimana perkawinan pada umumnya.Kawinfriend merupakan perkawinan alternatif yang pas sebagai sarana untuk memenuhi kebutuhan biologisnya. Sebab salah satu faktor utama yang mendorongnya untuk melakukan kawin friend tiada lain hanyalah untuk mencari kehangatan belaka. Bagi wanita sukses seperti dia, faktor ekonomi tidak lagi menjadi modal penting yang perlu dipertimbangkan dalam perkawinan (Marmi, 2017: 20). Lebih lanjut ia munuturkan, dengan kawin friend ini, istri bisa terbebas dari hegemoni suami. Posisi suami tidak harus menjadi sosok yang sewaktu-waktu harus mengikat kehidupan sang istri. Di samping itu, dengan kawinfriend ini pula, istri juga tidak harus tinggal serumah dengan suami.Inilah yang melatarbelakangi terjadinya kawin friendbagi wanita seperti Marmi ini.

Hal yang sama disampaikan oleh Tania_-seorang wanit keturunan Arab-dia tinggal di Perumahan Bulak Rukem dan sudah menjada lima tahun yang lalu. Dia mengungkapkan pada peneliti bahwa dirinya melakukan model kawin friend. Wanita murah senyum ini, menuturkan bahwa model kawin friend ini cocok sekali bagi dirinya.Dalam keluarga kawin friendini, istri menanggung nafkah keluarga. Menurut wanita pengusaha minyak parfom ini, ketika istri menanggung seluruh nafkah keluarga maka istri yang menjadi kepala rumah tangga dan suami sebagai "bawahan" yang tidak punya wewenang untuk memerintah istri. Menurutnya, model kawin friend ini sangat membantu dirinya untuk lebih semangat menghadapi tantangan hidup di dunia ini. Dengan kawin friend, seseorang akan bisa merasakan kehangatan sebagaimana layaknya suami istri, namun di sisi lain istri tidak harus patuh pada suami bahkan suami harus selalu patuh pada istri(Tania, 2017: 11).

Kedua, mirip Kawin Sirr. Ismaya, seorang wanita single parent yang tinggal di salah satu komplek perumahan Kebong Agung Asri.Ia mengaku pernah melakukan praktik kawin friend. Janda kaya raya yang memliki toko mas di Tunjungan Plaza ini juga mengungkapkan alasan yang tak jauh berbeda dengan wanita lain yang pernah melakukan praktik kawinfriend. Menurutnya, praktik kawin friend mirip dengan praktik kawin sirri..Artinya dalam praktiknya, tidak ada resepsi dan juga tidak ada pegawai dari pihak Kantor Urusan Agama (KUA) yang 
ljtihad: Jurnal Wacana Hukum Islam dan Kemanusiaan, Volume 18, No. 2, Desember 2018: 193-210

hadir untuk mencatatnya.Di samping itu, suami dalam kawin friend tidak tinggal dalam satu rumah, sehingga kestabilan dan ketenangan dalam keluarga— khususnya bagi anak-anaktidak terganggu dengan keberadaan suami (Ismaya, 2017: 5).Pada awalnyaia melakukan praktik kawin friend hanya sekedar coba-coba. Namun dari sinilah justru akhirnya ia menjadi ketagihan untuk terus melakukan praktik kawin friend. Tentunya, tidak perlu dipertanyakan berapa kali ia telah melakukannya.

Masih menurut Ismaya, dengan model kawin friend ini, istri tidak perlu ribet-ribet dengan urusan rumah tangga.Terlebih bagi wanita seperti dia yang notabene hanya sekedar untuk mendapat belaian seorang laki-laki semata.Karena dengan praktik kawin friend istri tidak perlu untuk tinggal dalam satu atap dengan suaminya.Istri tinggal memanggil suaminya bilaia sedang membutuhkannya.Tentunnya kebutuhan ini hanya sebatas untuk merasakan kehangatan dan pemuas nafsu biologis semata. "Hal ini memudahkan bagi saya untuk tetap berhubungan dengan pria lain"tuturnya pada peneliti (Ismaya, 2017: 5)..

Ketiga, mudah proses perceraiannya. Aprilia, wanita seksi yang belum pernah mekawin sebelumnya, mengaku bahwa dia memilih model kawin friend karena dalam kawin ini tidak ada resepsi dan balik kloso— istilah ini digunakan orang Jawa ketika mau melakukan resepsi di rumah keluarga mempelai putra.Sebab pihak keluarga masing-masing suami-istri tidak saling mengetahui. Namun yang terpenting, proses pelaksanaan "kawin friendtidak dicatat di Kantor Urusan Agama, sehingga dalam proses perceraiannya pun tidak terlalu sulit dan bisa diselesaikan mereka berdua," tuturnya pada peneliti. Wanita yang penghasilannya lebih dari 20 juta perbulannya ini tinggal di kawasan perumahan elit Palm Spring Regency.Di kompleks perumahan ini dia tinggal seorang diri ditemani seorang pembantu.Namun, sebenarnya dia sudah bersuami dan suaminya di luar Surabaya.Setiap dia membutuhkan kehadiran suami, cukup menelponya dan bertemua di tempat yang telah disepakati bersama (Aprilia, 2017: 10). Hampir sama dengan Aprilia, Ibu Kalisa, seorang janda yang terkenal dengan julukan "Ratu Kos" di daerah Surabaya Utara ini menuturkan pada peneliti bahwa dia sudah melakukan kawin friend berulang-ulang. Wanita yang suka laki-laki brondong ini mengaku bahwa dirinya memilih kawin friendkarena proses perkawinan dan perceraiannya mudah dan sangat praktis. Dengan demikian, kata wanita mungil ini, "enak, aku iso gampang le wis bosen lan gampang le pengen golek mane", tuturnya pada peneliti (Kalisa, 2017: 29). 
Keempat, ganti-ganti pasangan.Susi, seorang gadis yang berusia matang.Ia menceritakan bahwa perkawinan yang ia lakukan adalah praktik kawin friend bahkan ia sudah melakukannya berulang-ulang. Lela sengaja tidak memilih model pernikahan seperti pada umumnya, supaya ia bisa mudah untuk gonta ganti pasangan (Susi, 2017: 10). Demikian juga dengan Qibtia, seorang janda kaya raya asal Pasuruan.Ia juga mengaku pernah melakukan kawin frienddengan salah seorang tokoh agama di Surabaya.Namun dia tidak mau menyebutkan profesi suami friend -nya itu.Menurutnya, awal mula melakukan model perkawinan friendini adalah ikut-ikutan aja dan cuma coba-coba.Akan tetapi setelah dirasakan bahwa perkawinannya berlangsung tiga bulan, dia merasa nyaman dan cocok dengan suami friend -nya ini.Akhirnya, diapun sepakat dengan suaminya untuk meresmikan kawin friend-nya menjadi kawin 'urfi>, sebagaimana perkawinan pada umumnya. Mereka berdua pun sepakat untuk mencatatkan perkawinannya dengan cara mendaftarkan perkawinannya di KUA. Akhirnya, perkawinan Rika dengan tokoh agama ini resmi menjadi suami istridan sekarang tinggal di Perumahan Kebong Agung Surabaya (Qibtia, 2017: 9).

Kelima, Memperbaiki keturunan. Ada yang menarik dari motif praktik friend yang dilakukan oleh para wanita karier ini, yaitu ada yang bertujuan untuk memperbaiki keturuan. Mia, misalnya, dia sudah melakukan kawin frienddengan laki-laki Timur Tengah. Sesuai dengan pengakuannya, ibu beranak dua ini, menjelaskan bahwa ia memilih model kawin friend, karena ia ingin memperbaiki keturuan dan tentunya juga menguasai menjadi penguasa dalam rumah tangganya. Artinya, mulai dari nafkah, hubungan suami istri, bahkan sampai perceraian pun pihak perempuan yang menentukan (Mia, 2017: 4).

\section{Gigolo dalam kaitannya dengan kawin friend}

Tingkat kesulitan mencari data para suami kawin friend ini jauh lebih tinggi dari pada mencari data para wanita pelaku kawin friend.Hingga selesainya penyusunan penelitian ini, peneliti hanya menjumpai dua orang suami pelaku kawin friend.Suami kawin friend dan para gigolo itu hampir sama. Suami kawin memburu harta dengan cara melayani para wanita sosialita, begitupun dengan para gigolo juga memburu harta dengan melayani para wanita sosialita. Namun yang membedakan di antara keduanya adalah proses awal transaksinya. Proses tansaksi suami kawin friend sudah memenuhi persyaratan dalam akad nikah yang Islami, 
ljtihad: Jurnal Wacana Hukum Islam dan Kemanusiaan, Volume 18, No. 2, Desember 2018: 193-210

sedangkan dalam dalam praktik gigolo tidak ada akad nikah. Akan tetapi pada tujuan dan praktik selanjutnya, baik suami frienda maupun pelaku gigolo itu sama tidak ada bedanya.

Tingkat kesulitan mencari data tentang pelaku friend (suami friend) lebih tinggi jika dibandingkan dengan data tentang pelaku gigolo.Oleh karena itu, dalam penelitian ini, peneliti hanya menyajikan data para pelaku friend, sebab penjelasan tentang pelaku gigolo itu sudah maklum dan banyak penelitian tentang itu.Pertama, 'Samsul' adalah seorang suami kawin friend.Laki-laki berusia 38 tahun ini mengaku bahwa dia adalah suami kawin friend dari seorang sosialita kaya raya.Awalnya, menurut Dono, perkawinan yang dilakukannya itu tidak ada bedanya dengan perkawinan pada umumnya.Hanya saja dalam perkawinan ini, suami tidak diharuskan menanggung biaya hidup istri, sebab istrinya sudah tidak membutuhkan biaya dari suami-mengingat dia wanita karier yang kaya raya—bahkan suami yang selalu dibiayai oleh istri. Namun, ketika masa perkawinannya sudah lewat setengah tahun, Dono dan istrinya sepakat untuk mendaftarkan perkawinannya di KUA dan sekrang menetap di daerah Jambangan Surabaya Selatan (Samsul, 2017: 24).Ketertarikan Samsul untuk menerima tawaran kawin friend, dikarenakan dia sudah lama mencari calon istri tapi tidak pernah berhasil. Oleh karena itu, ketika ada seorang wanita yang mengajaknya kawin, maka ia pun tidak menyia-nyiakan kesempatan tersebut. "Apa lagi calonnya punya penghalisan di atas 20 juta perbulan, ge boten apik. le' nolak."tuturnya pada peneliti (Samsul, 2017: 11).

Kedua, 'Jono' yang juga pernah melakukan kawin frienddengan seorang wanita pemilik perusahaan.Jono adalah seorang manajer di salah satu perusahaan besar di Kabupaten Gresik. Ia mengaku bahwa dirinya melakukan 'perkawinan' (friend) dengan seorang Tante yang tidak lain adalah atasannya sendiri. Jono sebagai seorang laki-laki gagah dan berperawakan tampan ini, tidak heran kalau banyak wanita yang terpikat dengan ketampanannya.Termasuk juga bosnya sendiri (Jono, 2017: 11).Menurutnya, perkawinan ini dilakukan tanpa sepengetahuan keluarga masing-masing.Akan tetapi perkawinan tersebut kandas di tengah jalan. Artinya, usia perkawinannya tidak sampai satu tahun sudah cerai.Awalnya, Jono tidak ada niatan untuk menerima pinangan bosnya itu.Namun ketika bosnya itu terus menerus mendesak dia untuk menerima ajakan kawinnya, maka dia menerimanya dengan satu syarat agar perkawinannya tidak diketahui oleh orang banyak.Akhirnya, terjadilah perkawinan itu tanpa diketahui oleh pihak keluarga masing-masing. Sedangkan walinya memakai wali mudin 
(mub\}ak.kam) dan dilaksanakan di Bondowoso (Jono,2017: 11).Menurut Jono, istrinya yang merupakan pengusaha sukses itu tidak menuntut apa-apa. Hanya saja dia harus selalu siap selama 24 jam untuk menerima ajakan istrinya, baik untuk bermalam di hotel atau sekedar menemaninya jalan-jalan. Hal itu sudah disanggupinya sebelum perkawinan terjadi, sebab sebelum perkawinan, pihak wanita meminta tiga hal: Pertama, suami bebas dari segala tanggang jawab layaknya suami pada umumnya. Kedua, suami harus selalu siap melayani istri, kapan pun dan di mana pun.Ketiga, perkawinannya dirahasiakan dari siapa pun, bahkan dari pihak keluarga masing-masing(Jono, 2017:11).

\section{Analisis praktik friend oleh para wanita sosialita}

Untuk lebih memperjelasn tujuan pelaksanaan perkawinan friend bagi wanit karier di Surabaya, peneliti menggunakan teori fungsionalisme struktural ini diusung oleh Robet Merton (Ritzer, 1982: 141). Ia menulis beberapa pernyataan terpenting tentang fungsi dalam kajian sosiologi. Merton memperkenalkan konsep fungsi nyata (manifest) dan fungsi tersembunyi (latentt). Menurut pengertian sederhana, fungsi nyata adalah fungsi yang diharapkan, sedangkan fungsi yang tersembunyi adalah fungsi yang tidak diharapkan (Ritzer, 1982: 141).Fungsi nyata dari praktik kawin friendadalah untuk memberikan solusi bagi para wanita karier kaya yang sibuk dan tidak sempat memikirkan masalah perkawinan. Dengan adanya kawin friend ini para wanita lajang bisa segera menemukan pasangan hidupnya, sebab lelaki yang akan mekawin dengannya tidak dikenai biaya sedikit pun. Di samping itu juga berfungsi untuk meringankan dan membebaskan suami dari segala tanggung jawab yang diembannya.Namun demikian, selain fungsi manifest tersebut, terdapat fungsi yang tersembunyi, yang oleh Merton disebut fungsi latent, yaitu keberadaan kawin friendini berfungsi sebagai lahan untuk mencari kepuasan seksualitas melalui pasangan-pasangan yang dipilihnya, sebab tidak semua lelaki bisa diterima sebagai calon suami kawin friend ini.

Pemikiran ini dapat dihubungkan dengan konsep lain Merton-yakni akibat yang tidak diharapkan (unanticipated consequences). Tindakan mempunyai akibat, baik yang diharapkan maupun yang tidak diharapkan.Meskipun setiap orang menyadari akibat yang diharapkan, analisis sosiologi diperlukan untuk menemukan akibat yang tidak diharapkan ini.Bahkan beberapa pakar menganggap ini adalah esensi dasar dari sosiologi (Ritzer, 1982: 142). 
ljtihad: Jurnal Wacana Hukum Islam dan Kemanusiaan, Volume 18, No. 2, Desember 2018: 193-210

Merton menjelaskan bahwa akibat yang tidak diharapkan, tidak sama dengan fungsi yang tersembunyi. Fungsi yang tersembunyi adalah suatu jenis dari akibat yang tidak diharapkan, satu jenis yang fungsional untuk sistem tertentu. Tetapi ada dua tipe lain dari akibat yang tidak diharapkan; yang disfungsional untuk sistem tertentu dan ini terdiri dari disfungsi tersembunyi dan yang tidak relevan dengan system yang dipengaruhinya, baik secara fungsional atau disfungsional, atau bahkan kosekuensi nonfungsionalnya (Ritzer, 1982: 145).

Dalam kaitannya dengan praktik kawin friend bagi wanita karier, teori fungsi ini menurut hemat peneliti sangat cocok untuk digunakan sebagai pisau analisis praktik kawi friend itu sendiri. Sesuai dengan dua fungsi yang kemukakan oleh Merton di atas, yaitu funsi manifest dan fungsi latent. Dalam praktik kawin friend ini, ternyata tujuan para wanita tersebut melakukan kawin friendadalah untuk membebaskan para suami dari segala tanggungan nafkah. Pembebasan nafkah ini peneliti masukkan ke dalam fungsi manifest, yaitu fungsi yang jelas dan nyata sesuai dengan prinsip awal digagasnya model perkawinan friend ini. Mereka membebasan para suami dari segala tanggungan nafkah dilandasi beberapan alasan agar suami mau kawin dengan dirinya. Sebab, jika nafkah tidak dibebaskan, mereka tentu akan sulit mencari laki-laki yang mau bersedia untuk mengawininya mengingat dia seorang janda yang sudah beranak, usianya sudah agak tua atau juga dia seorang gadis yang usianya sudah tua dan berparas kurang menarik.

Di balik fungsi yang nyata itu, ternyata praktik kawin friend ini mempunyai fungsi latent, yaitu fungsi yang tersembunyi dan tidak diketahui oleh orang banyak. Sebab, ternyata mereka melakuka kawin friend ini bertujuan sebagaimana berikut:Pertama, agar nafsu biolgis terpuaskan. Seperti halnya perkawinan yang dilakukan oleh Mimi, Titin, Ira, Mumun, dan Rika. Kedua, agar terlepas dari hegemoni patriarki. Seperti halnya perkawinan yang dilakukan oleh Mimi dan Titin.Ketiga, agar leluasa menentukan pasangan. Seperti halnya perkawinan yang dilakukan oleh Ira, Susi dan Mumun.Keempat, agar mudah proses perceraiannya. Seperti halnya perkawinan yang dilakukan oleh Titin, Ira, Susi, Lela dan Mumun. 
Tabel wanita sosialita pelaku kawin friend di kota Surabaya

\begin{tabular}{|c|c|c|c|c|}
\hline No & $\begin{array}{c}\text { Nama } \\
\text { Pelaku } \\
\text { Kawin Friend }\end{array}$ & $\begin{array}{c}\text { Alasan } \\
\text { Memilih } \\
\text { KawinFriend }\end{array}$ & $\begin{array}{c}\text { Akhir Pernjalanan } \\
\text { Kawin Friend }\end{array}$ & Keterangan \\
\hline 01 & $\begin{array}{l}\text { Aprilia (wanita } \\
\text { single parent yang } \\
\text { kaya raya) }\end{array}$ & $\begin{array}{l}\text { Agar terbebas dari } \\
\text { hegemoni suami. }\end{array}$ & $\begin{array}{l}\text { Pekawinannya tidak } \\
\text { bertahan lama, karena } \\
\text { setelah itu dia memilih } \\
\text { untuk berpisah } \\
\text { dengan suami } \\
\text { friendnya. }\end{array}$ & $\begin{array}{l}\text { Ia tinggal } \\
\text { di komplek } \\
\text { Perumahan } \\
\text { Graha Family } \\
\text { dekat Kecamatan } \\
\text { Wiyung Surabaya. }\end{array}$ \\
\hline 02 & $\begin{array}{l}\text { Tania (wanita } \\
\text { keturunan Arab } \\
\text { yang menjanda } \\
\text { selama } 5 \text { thn) }\end{array}$ & $\begin{array}{l}\text { Agar terbebas dari } \\
\text { hegemoni suami. }\end{array}$ & $\begin{array}{l}\text { Perkawinan friendnya } \\
\text { tidak bertahan lama. }\end{array}$ & $\begin{array}{l}\text { Ia tinggal di } \\
\text { Perumahan } \\
\text { Kebon Agung } \\
\text { Asri Surabaya }\end{array}$ \\
\hline 03 & $\begin{array}{l}\text { Qibitia(wanita } \\
\text { single parent } \\
\text { berparas } \\
\text { cantik). }\end{array}$ & $\begin{array}{l}\text { Kawinfriendmirip } \\
\text { dengan kawin } \\
\text { sirri yang tidak } \\
\text { perlu didaftarkan } \\
\text { Kantor Urusan } \\
\text { Agama. }\end{array}$ & $\begin{array}{l}\text { Melakukan kawin } \\
\text { friend berulang-ulang } \\
\text { dan berakhir dengan } \\
\text { perceraian. }\end{array}$ & $\begin{array}{l}\text { Ia seorang janda } \\
\text { pemilik salah satu } \\
\text { toko mas di TP. } \\
\text { Ia tinggal di salah } \\
\text { satu komplek } \\
\text { perumahan Bulak } \\
\text { Rukem Surabaya }\end{array}$ \\
\hline 04 & $\begin{array}{l}\text { Mia (wanita } \\
\text { gadis cantik dan } \\
\text { seksi) }\end{array}$ & $\begin{array}{l}\text { Proses } \\
\text { perceraiannya } \\
\text { mudah selesai dan } \\
\text { tidak ribet }\end{array}$ & $\begin{array}{l}\text { Berakhir dengan } \\
\text { perceraian }\end{array}$ & $\begin{array}{l}\text { Wanita yang sudah } \\
\text { bersuami dan } \\
\text { suaminya tinggal } \\
\text { di luar kota. Ia } \\
\text { tinggal di salah } \\
\text { satu kompleks } \\
\text { Perumahan Palm } \\
\text { Spring Regency }\end{array}$ \\
\hline 05 & $\begin{array}{l}\text { Susi (janda ratu } \\
\text { kos-kosan asal } \\
\text { Batak) }\end{array}$ & $\begin{array}{l}\text { Proses } \\
\text { perceraiannya } \\
\text { cepat selesai }\end{array}$ & $\begin{array}{l}\text { Ia melakukan kawin } \\
\text { friendberulang-ulang } \\
\text { namun selalau } \\
\text { berakhir dengan } \\
\text { perceraian }\end{array}$ & $\begin{array}{l}\text { Ia seorang janda } \\
\text { yang sudah } \\
\text { berulang kali } \\
\text { melakukan } \\
\text { kawinkawin } \\
\text { frienddengan para } \\
\text { berondong }\end{array}$ \\
\hline
\end{tabular}


ljtihad: Jurnal Wacana Hukum Islam dan Kemanusiaan, Volume 18, No. 2, Desember 2018: $193-210$

\begin{tabular}{|c|c|c|c|c|}
\hline No & $\begin{array}{c}\text { Nama } \\
\text { Pelaku } \\
\text { Kawin Friend }\end{array}$ & $\begin{array}{c}\text { Alasan } \\
\text { Memilih } \\
\text { KawinFriend }\end{array}$ & $\begin{array}{c}\text { Akhir Pernjalanan } \\
\text { Kawin Friend }\end{array}$ & Keterangan \\
\hline 06 & $\begin{array}{l}\text { Rika (Janda asal } \\
\text { Pasuruan) }\end{array}$ & $\begin{array}{l}\text { Mudah gonta } \\
\text { ganti pasangan }\end{array}$ & $\begin{array}{l}\text { Perkawinannya } \\
\text { bertahan sampai } \\
\text { sekarang. Sebab, } \\
\text { dia memilih untuk } \\
\text { meresmikan kawin } \\
\text { friendnya tersebut di } \\
\text { KUA }\end{array}$ & $\begin{array}{l}\text { Ia seorang janda } \\
\text { yang mekawin } \\
\text { friend dengan } \\
\text { salah satu } \\
\text { tokoh agama } \\
\text { di Surabaya. } \\
\text { Dan sekarang } \\
\text { tinggal salah satu } \\
\text { perumahan di } \\
\text { Surabaya Selatan. }\end{array}$ \\
\hline 07 & $\begin{array}{l}\text { Lela (gadis } \\
\text { langsing berusia } \\
\text { matang) }\end{array}$ & $\begin{array}{l}\text { Mudah gonta } \\
\text { ganti pasangan }\end{array}$ & $\begin{array}{l}\text { Perkawinan yang ia } \\
\text { lakukan bertahan } \\
\text { hanya beberapa bulan. }\end{array}$ & $\begin{array}{l}\text { Ia pernah kawin } \\
\text { friendberulang- } \\
\text { ulang. }\end{array}$ \\
\hline 08 & $\begin{array}{l}\text { Suti (Janda } \\
2 \text { anak asal } \\
\text { Pasuruan) }\end{array}$ & $\begin{array}{l}\text { Memperbaiki } \\
\text { keturunan }\end{array}$ & $\begin{array}{l}\text { Perkawinannya } \\
\text { bertahan hanya } \\
\text { sampai } 3 \text { tahun. }\end{array}$ & $\begin{array}{l}\text { Ia mekawin } \\
\text { dengan orang } \\
\text { Arab dan } \\
\text { mempunyai } 2 \\
\text { orang anak. }\end{array}$ \\
\hline
\end{tabular}

Dari tabel tersebut di atas, peneliti bisa menyimpulkan bahwa rata-rata perkawinan friend berakhir dengan perceraian. Tepatnya, kalau diprosentase bahwa akhir dari pasangan suamiistri yang memilih model kawin friendada sekitar $89 \%$ berakhir dengan perceraian dan hanya $11 \%$ yang memilih untuk mempertahankan perkawinannya.

Adapun motif para pelaku kawin friend, semuanya untuk mencari kesenangan semata atau $100 \%$ untuk mencari kepuasan biologis.Tidak ada satu orang pun yang melakukan kawin firendini bertujuan meringankan suami, mengurangi beban kewajiban suami, atau sebagai solusi bagi para wanit karier yang sangat sibuk dengan kariernya, sebagaimana yang telah difatwahalalkan oleh Shaykh Muhammad Yūsuf al-Qarḍ̄āwi. Di mana al-Qarḍ̄āì menegaskan bahwa perkawinan firendadalah perkawinan alternatif bagi para wanita karier yang tidak sempat memikirkan prihal perkawinan dan tidak mau terbebani dengan keberadaan suami. 
Membongkar praktik kawin friend para wanita sosialita di Surabaya (Nasiri)

\section{Penutup}

Praktik kawin firendbagi para wanita sosialita di Surabaya ada dua model.Pertama, kawin friend dilakukan dengan cara mencari informasi dari teman atau media massa mengenai laki-laki yang hendak dipinangnya. Setelah menemukan, mereka mencari tokoh agama (mudin) untuk menikahkanmereka berdua.Kedua, kawin firenddilakukan dengan cara pengamatan yang agak lama dan tanpa melalui perantara media massa atau teman. Setelah menemukan calonnya, mereka melakukan perkawinan di tempat yang jauh dengan jarak masāfat al-qaṣr atau di luar negeri.

Bahwa para wanita sosialita di Surabayayang melakukan praktik kawin firendtersebut mempunyai dua tujuan. Pertama, tujuan manivest (nyata).Mereka memilih praktik kawin firend dengan tujuanuntuk membebaskan para suami dari segala tanggungan nafkah.Hal itu mereka lakukan agar suami mau kawin dengan dirinya. Sebab, jika nafkah tidak dibebaskan, mereka tentu akan sulit mencari laki-laki yang mau bersedia untuk mengawininya mengingat dia seorang janda yang sudah beranak, usianya sudah agak tua atau juga dia seorang gadis yang usianya sudah tua dan berparas kurang menarik. Kedua, tujuan laten (tersembunyi). Mereka memilih praktik kawin firenddengan tujuan untuk mencari kepuasan biologis semata.

Ulama fikih berbeda pendapat dalam menyikapi praktik kawin friend di Surabaya.Di antara mereka ada yang memperbolehkan (menghalalkan) karena mereka melihat syarat rukun pernikahan sudah dipenuhi.Ada yang yang mengharamkan dan harus ditinggalkan model kawin friend ini, hal itu dikarenakan madarrat (bahaya) yang diakibatkan dari praktik friend ini.Menurut mereka model kawin friend ini tidak ada bedanya dengan praktik sewa gigolo.

\section{Daftar pustaka}

Al-Sabuni, Muhammad 'Ali. Rawā'i' al-Bayān Tafsir Ayāt al-Aḥkām Min al-Qur'ān, Juz I. Beirut: Dar Al-Fikr, t.t.

Fahmie, Anshori. Siapa Bilang Poligami itu Sunnah?. Bandung: Pustaka IIMaN, 2007.

Hakim, Rahmat. Hukum Perkawinan Islam. Bandung: CV. Pustaka Setia, 2000.

Haqqī, Khashi,'. Ta'addud al-Zawjāt waTa'addud al-'Ashiqāt. Beirut: Dā,r IbnuHazm, 1997.

Hifni, Mohammad. "Bu Nyai dan Poligami: Studi Konstruksi Sosial Bu Nyai yang di Poligami tentang konsep Mawaddahwa Rạ̣mah di Bangkalan Madura," Tesis, IAIN Sunan Ampel Surabaya, 2008.

Hilmy, Ummu. Poligami di Kalangan Burub Perempuan, (Study Pada Burub Industri dan Buruh Migran), dalam Wacana Poligamai di Indonesia. Bandung: Mizan, 2005. 
ljtihad: Jurnal Wacana Hukum Islam dan Kemanusiaan, Volume 18, No. 2, Desember 2018: 193-210

Jones, Jamilah. Plural Marriage in Islam, Terj. Machnun Husein. Jakarta: PT. Raja Grafindo Persada, 2001.

Kodir, Faqihuddin Abdul. Memilih Monogami; Pembacaan atas al-Qur'an dan Hadith Nabi. Yogyakarta: Pustaka Pesantren, 2005.

Manan, Abdul. Aneka Masalah Hukum Perdata Islam di Indonesia. Jakarta: Kencana Prenada Media Group, 2008.

Mulia, Siti Muzdah. Islam Menggugat Poligami. Bandung: Pustaka Indah, 2005.

Mulk bin Yusuf al-Mutaq, Abdul. Zawaj al-Friend Bayna Hukmibi al-Syar'i wa Waqi'ubu al-Ma'asir Zawaju al-Asdiqa', Dar al-'Asimah: Riyadh, 2006.

Mustaqim, Abdul. "Konsep Poligami Menurut Muhammad Syahrur" Jurnal Studi Ilmu-ilmu al-Qur'an dan Hadith, Volume 8, Nomor 1, 2007.

Mustofa, Agus. PoligamiYunk!! Surabaya: PADMA Press, t.t.

Nuruddin, Amiur. Dan Azhari Akmal Tarigan. Hukum Perdata Islam di Indonesia; Studi Kritis Perkembangan Hukum Islam dari Fikih, UU no 1 tabun 1974 sampai KHI. Jakarta: Kencana Prenada Media Group, 2006.

Qardhawi, Yusuf. Halal dan Haram dalam Islam,Terj.Abu Sa’id Al-Falahi. Jakarta: Robbani Press, 2000.

Sabiq, Sayyid..Fikih Sunnah, Jilid 3, Terj. Nor Hasanuddin. Jakarta: Pena Pundi Aksara, 2007

Salim, M. Agus. "Kecenderungan Nikah Poligami dengan Nikah Sirri di Kabupaten Bangkalan” Skripsi, IAIN Sunan Ampel Surabaya, 2004.

Salman, Abdul Matin. Pendidikan Poligami: Pemikiran dan Upaya Pencerahan Puspo Wardoyo tentang Poligami. Solo: CV. Bumi Wacana, 2008.

Satiaji, Ahmad. AA Gym: Mengapa Berpoligami. Yogyakarta: Qultum Media, 2006.

Shihab, M. Quraish. Tafsir al-Misbab; (Pesan, Kesandan Keserasian al-Qur'an), Vol. II. Jakarta: Lentera Hati, 2006.

Suryo. Genetika, Cet. Ke 8. Yogyakarta: Gajah Mada University Press, 1998.

Syafe'i, Rachmat. Ilmu Usul Fikih. Bandung: CV. Pustaka Setia, 1999.

Thalib, Sayuti. Hukum Kekeluargaan Indonesia. Jakarta: Penerbit Universitas Indonesia Press, 2007.

Tutik, Titik Triwulan dan Trianto. Poligami Perspektif Perikatan Nikah; Telaah Kontekstual menurut Hukum Islam dan Undang-undang Perkawinan Nomor 1 Tabun 1974. Jakarta: Prestasi Pustaka, 1997.

Witular, Abraham Silo. Poligami Nabi Kajian Kritis Teologis Terbadap Pemikiran 'Ali Syariati dan Fatimah Mernissi. Yogyakarta: Pustaka Riḥlah, 2006. 